\title{
GRAMMAR LESSONS LEARNED: DEPENDENT CLAUSES, FALSE COGNATES, AND OTHER PROBLEMS IN RULE OF LAW PROGRAMMING
}

\author{
Wade Channell ${ }^{*}$
}

The international donor community has spent decades working with developing countries to guide, promote, and even demand reforms aimed at improving socio-economic and political performance across a wide range of standards. One of the most prominent objectives has been to instill and establish stable rule of law where it is feeble or fractured, for a variety of noble reasons. Success in these endeavors has all too often been limited or temporary; positive gains, such as improved constitutions, are often offset by implementation and enforcement failures. ${ }^{1}$

Development assistance often focuses on the methods by which rule of law (ROL) is implemented. These technocratic or managerial solutions are only effective, however, if they are based on a proper understanding of the socio-political underpinnings of the work they are designed to advance. ${ }^{2}$ If the basic concept is wrong, then the mechanisms for achieving it are likely to be wrong. It is not good enough simply to do the wrong thing better. Improved delivery may require more than improved techniques; perhaps the fundamental failure is one of ideas, reflected and exacerbated, as this article will argue, in the very language of ROL reform. Some simple grammar lessons may help to reorient programming for effectiveness.

\footnotetext{
* Wade Channell, JD, is a Senior Legal Reform advisor for the United States Agency for International Development (USAID) and a career legal reform specialist. The views and opinions presented in this paper are his alone and do not necessarily reflect the position of the United States Government or USAID. Fortunately, the views and opinions have been improved through the thoughtful input of a cadre of outstanding development professionals. The author is grateful to Ken Baum, Karol Boudreaux, Nick Klissas, Joe Lowther, Greg Maassen, Olin McGill, Elizabeth Shackelford, Veronica Taylor, Mark Walter and Louise Williams for their input, encouragement, and disagreements during the development of these concepts; all weaknesses in thought or delivery are attributable to the author alone, not to these invaluable colleagues.

1. See Jan Stromsem et al., Africa Regional Rule of Law Status Review 15 (2007), http://pdf.usaid.gov/pdf_docs/PNADO804.pdf.

2. Wil Hout, Governance and the Rhetoric of International Development 13 (May 27, 2010), available at $\mathrm{http}: / /$ campus.iss.nl/ hout/Inaugural\%2027\%20May\%202010.pdf.
} 


\section{Can External ROL Programs Have a Positive Impact?}

The need for rule of law is a foregone conclusion among development practitioners. ROL is recognized as the foundation for establishing and protecting fundamental human rights, and is increasingly understood as an essential component for long-term, stable economic growth. ${ }^{3}$ Yet consistent underperformance - and outright failure - of many programs calls into question whether external programs can positively influence the development of rule of law. The answer is not immediately clear.

The Paris Declaration on Aid Effectiveness recognizes that intentions in aid provision do not always match results, whether in rule of law, health, economic growth, or other targets of assistance. Deficiencies in aid delivery have been the subject of renewed critique in recent years. Moyo has recommended an end to aid, citing the deleterious effects foreign development funding seems to have had on long-term government performance in Africa. ${ }^{4}$ Easterly is just as negative, questioning the effectiveness of "planners" who provide advice and funding to developing country counterparts through supply-side interventions, but with little to show for it among the alleged beneficiaries. $^{5}$

The Paris Declaration and the subsequent Accra Agenda for Action ${ }^{6}$ assume that external assistance can have a positive internal impact, and call for technocratic improvements in the delivery mechanisms through better collaboration among donors and partner governments, as well as greater external respect for internal priorities, plans, and objectives. Moyo and Easterly insist that external assistance has had a net negative impact, particularly on rule of law. While it is safe to say that donor interventions make a difference, the issue is whether that difference is positive or negative.

Every interaction between governments has an impact on the rule of law. Each development project, trade negotiation, military campaign, or sovereign loan either promotes or undermines rule of law. This can occur through deliberate attempts to promote positive change, or through passive failure to

3. See generally Morton H. Halperin et al., The Democracy Advantage: How Democracies Promote Prosperity and Peace (2005).

4. See Dambisa Moyo, Dead Aid: Why Aid is Not Working and How There is Another Way FOR AFRICA, at xix (2000).

5. See generally William Easterly, The White Man's Burden: Why the West's Efforts to Aid the Rest Have Done So Much Ill and So Little Good (2007).

6. See generally Third High Level Forum on Aid Effectiveness, Accra, Accra Agenda for Action (Sept. 2-4, 2008), http://siteresources.worldbank.org/ACCRAEXT/Resources/4700790-1217425866038/ AAA-4-SEPTEMBER-FINAL-16h00.pdf. 
challenge a sub-par status quo. When short-term foreign policy objectives allow an ROL underperformer to go unchallenged for violations of human rights, even longer-term project assistance to improve governance may not be able to counter the damage. There are no neutral engagements.

Given that neutrality is not an option, development practitioners ${ }^{7}$ have a mandate to do no harm in rule of law programming. Yet this mandate goes further: it encompasses an obligation to promote positive change, not only in ROL projects, but also in all other programming in which law or government is a component, be it economic growth, health, education or emergency humanitarian response. Unfortunately, current approaches have not always proven to be harmless, much less helpful, because they are often fundamentally flawed at inception.

To rethink the goals and methods, it may be helpful introduce a new perspective. In short, rule of law programming has some grammar problems. Definitions may be well phrased, laws and decrees may be well written, but problems lurk in the underlying structure of thought. The language of reform is flawed; therefore, a grammar lens may be just the tool for re-envisioning the goals and methods of rule of law programming.

\section{Defining "Rule of Law"}

Any useful analysis of rule of law must begin with a definition. Kleinfeld has exposed a serious defect in ROL discussions, finding that there are at least five separate and distinct definitions. ${ }^{8}$ These are often used simultaneously, without conscious knowledge by the discussants that they may be talking about remarkably different principles. It is no wonder that some of these discussions produce so little fruit.

One of the more comprehensive definitions of the term has been promulgated by the United Nations. Although imperfect, it is broadly accepted, at least rhetorically, by a great many of the world's nations. According to this formulation, the "rule of law" is:

7. Most rule of law projects are funded by government and government-funded organizations, including government agencies such as the U.S. Agency for International Development and the UK's Department for International Development, multilateral financial institutions such as the World Bank or African Development Bank, and a host of governance-related non-governmental organizations that receive significant funding from governments. For purposes of this paper, all projects and interventions discussed represent direct or indirect assistance by one government to another.

8. Rachel Kleinfeld, Competing Definitions of the Rule of Law, in Promoting the Rule of LAW Abroad: In Search of Knowledge 31, 32 (Thomas Carothers ed., 2006). 
[A] principle of governance in which all persons, institutions and entities, public and private, including the State itself, are accountable to laws that are publicly promulgated, equally enforced and independently adjudicated, and which are consistent with international human rights norms and standards. It requires, as well, measures to ensure adherence to the principles of supremacy of law, equality before the law, accountability to the law, fairness in the application of the law, separation of powers, participation in decision-making, legal certainty, avoidance of arbitrariness and procedural and legal transparency. ${ }^{9}$

There is little to disagree with here. Yet the definition is incomplete on simple grammatical terms.

\section{The Problem of Dependent Clauses}

Grammatically speaking, the term "rule of law" consists of two parts: a noun ("rule") and a prepositional phrase ("of law"). That prepositional phrase is a dependent clause, modifying the type of rule being espoused. When leaders proclaim their commitment to rule of law, they are technically espousing a certain form of rule from among other options (such as rule by force or rule by divine right).

Rule of law quite obviously places emphasis on law. And that is exactly where much rule of law programming is focused. International technical assistance frequently concerns itself with getting laws right and ensuring that local legal practitioners understand how to interpret and enforce them according to their terms. This is appropriate. Better drafting, increased training for judges, and assistance to prosecutors, lawyers, and bailiffs are all needed. And sometimes these interventions produce positive results. Even so, they can easily miss the heart of the matter.

Rule of law is not about law, it is about rule. And getting rule right is the foundation for the laws by which rule is exercised. Legitimate rulers operating within legitimate systems will generally produce legitimate laws. The basis of that underlying legitimacy is relational - the relationship between the rulers and the ruled.

Rule is a thus relational term. It presupposes some form of understanding by which a government and the governed determine the rules of a given society and hold each other accountable to those rules. This relationship can be based on force, but force tends to be one-sided, where those who control it do not necessarily subject themselves to the same requirements as the

9. U.N. Secretary-General, The Rule of Law and Transitional Justice in Conflict and Post-Conflict Societies: Report of the Secretary-General, \ 6, U.N. Doc. S/2004/616 (Aug. 23, 2004). 
general populace. As such, force provides a poor basis for establishing rule of law, because it lacks mutual accountability through which the governed can require the government to obey the same rules.

Effective rule requires a high degree of legitimacy. Legitimacy has many components, ${ }^{10}$ but is essentially a relational term as well. The primary component tends to be participation, either directly or through representatives, of stakeholders who are to be governed by the law in question. The UN definition is correct when it proclaims that rule of law includes "participation in decision-making." Yet it is participation that is often missing in rule of law programs.

Rule of law assistance, to be effective, must address the relationships within society—not just laws that are utilized to govern those relationships. Where the relationship is perceived by significant numbers of the population to be illegitimate- such as colonial conquest or domestic subjugation based on ethnicity for example - then the laws emanating from the ruler will be perceived to be illegitimate, undermining compliance, and accountability.

The UN definition of rule of law captures this concept in part. Under that definition, everyone-public officials, private entities, individuals-is "accountable to laws." However, laws do not enforce themselves, but rather are enforced by people in an institutional context that may or may not promote accountability.

Fukuyama has described rule of law as a consensus where rulers are subject to law, ${ }^{11}$ that is, accountable under law derived from consensus. Consensus arises from a participatory relationship in which stakeholders (directly or through their representatives) identify their needs and engage in legitimate processes to address those needs. Consensus cannot be imposed or imported; it can be informed by "international best practices" or foreign expertise, but must arise internally before either the rules or the system of ruling are considered legitimate.

In Blood Done Sign My Name, a gripping narrative of civil rights reform in the American South after 1964, Timothy Tyson illustrates the problem of legitimacy in a fundamental rule of law issue:

10. See generally Wade Channell, Law as Relationship: Toward a More Effective and Ethical Legal Reform, ESR REV., 23 (Fall 2008), http://marriottschool.byu.edu/esrreview/view_archive_issue.cfm?issue $=$ fallo8, for one perspective in which the author examines legitimacy in terms of substance, process and representation.

11. Johns Hopkins University-The Paul H. Nitze School of Advanced International Studies, Professor Francis Fukuyama Delivered "Last Lecture" at SAIS on April 29, SAIS-JHU.edu (Apr. 29, 2010), http://www.sais-jhu.edu/news-and-events/spring2010.htm (click on the link for Professor Fukuyama's "Last Lecture" to view the video). 
The law meant little in Oxford [North Carolina in 1970]. Many people nowadays think that after the U.S. Congress passed the Civil Rights Act of 1964, which outlawed racial discrimination in public accommodations, café owners and city officials read the news in the morning paper and took down all those WHITES ONLY and COLORED signs by lunchtime. But this landmark legislation did not make a dent in Oxford. ${ }^{12}$

A sufficient number of Southern whites rejected the legitimacy of the Civil Rights Act and the "Northern" government that passed it, in part because of lingering negative memories of post-conflict reconstruction after the U.S. Civil War, which had ended a hundred years before. Relationships had to be slowly, deliberately, and consistently renegotiated over a course of decades to achieve progress, and the process is far from over, almost 50 years later.

Practitioners can learn from this experience. Legislative reform alone may bring little, if any, change. In fact, the impact of requiring equal access to public parks in Oxford, North Carolina was the opposite of that intended: the local government merely privatized the parks so that they could be run on a members-only basis, where members happened to be white. The actual reforms required a complex system of long-term efforts to renegotiate the power dynamics and social relationships. Legislation was used as a catalyst, but legislation had to be accompanied by a system of enforcement that was generally accepted as legitimate, even if particular goals were sometimes resented.

To correct some of the weaknesses in existing ROL assistance, it will be necessary to reconsider the goal and the methods by which rule of law is promoted. The aim should be to reform and strengthen relationships through meaningful participation in order to establish legitimate rules and rulers. Controversial legislation will be difficult to implement if the legislators or executive are held in disrepute by the general population, or if implantation is based on force instead of agreement. As Fukuyama has noted, "rule of law has to do with the way states relate to their citizens." ${ }^{\prime 13}$ Recognizing the dependency of law to rule is a good first step toward improved assistance. And it will take time.

12. Timothy B. Tyson, Blood Done Sign My Name: A True Story 18 (2004).

13. Francis Fukuyama, SAIS Foreign Policy Institute Senior Fellow, Lecture at the Bernard L. Schwartz Forum on Constructive Capitalism, School of Advanced International Studies: What Is Development (Apr. 29, 2010). 


\section{Deficient Definitions}

In addressing laws, the UN definition is narrow in scope, considering only "laws that are publicly promulgated"; that is, official legislation, regulations and decrees. Such documented legal acts must, of course, be a focal point of ROL reform. Experience in implementation however, suggests that the definition does not effectively capture the full range of law that should be considered in reform efforts. Moreover, the definition assumes that promulgation leads to knowledge which has lead to incomplete reforms because it fails to recognize the systemic requirements needed before promulgation can serve adequately as a proxy for implementation.

The commercial legal and institutional reform (CLIR) analytical methodology, ${ }^{14}$ devised by USAID over the past decade, begins with an analysis of publicly promulgated laws and regulations, guiding practitioners through a checklist of key components across a range of laws. This is only a starting point however; the methodology also requires an analysis of the social dynamics that drive or inhibit reform within an economy. Although the methodology for these less tangible factors is somewhat less robust than analyses of laws, the approach captures something often missing in rule of law work: The unpublished values, norms, and modes of behavior that occur either as adjuncts of published legislation or as a parallel system of rule.

A focus on official legislation can cause analysts to miss underlying sources for legislative reform and the nuances of rule. Legislation is just one layer of the social relationships established within a society to maintain stability. Rule takes place at a community level through custom and tradition, and these should be understood both as a source of legitimacy for structuring legislation as well as a parallel system that may need little more than recognition. Examples abound. In Senegal, markets employ a range of parallel dispute resolution systems that allow for predictable transactions and risk management among the actors. ${ }^{15}$ There is seldom the need for recourse to more expensive and complex formal systems. These customs, worked out among the actors over years of interaction, represent a system of rule that can be the foundation for a more formal ADR system as well as a font of evidence for court cases, but only if the value is recognized. In Afghanistan, upper tier

14. See generally USAID, About BizCLIR, BIZCLIR.COM, http://www.bizclir.com/cs/about_bizclir (last visited Oct. 9, 2010) (explaining CLIR methodology and its progeny).

15. Julie Pacquin, Business Law Transplants and Economic Development: An Empirical Study of Contract Enforcement in Dakar, Senegal (Jan. 2010) (unpublished Doctoral thesis, McGill University). 
business people established a customary shura ${ }^{16}$ to settle commercial disputes due to the failure of the formal judicial system. When these systems of selfrule are ignored, reform efforts are undermined.

Custom and tradition can also serve as important sources of recognized yet unofficial law for the reform of legislation. In West Africa, there is a strong tradition of debt forgiveness that can inform preparation of modern bankruptcy codes. As just noted, customary dispute resolution systems can be the basis for rethinking court reform to capture the best of tradition within the formal institutional system. Rather than ignore custom - which is merely a form of common law without the same level of academic rigor-reforms would do well to craft conflicts of laws rule that recognize and incorporate custom and tradition.

Of course, there are limits. There are traditions that violate basic human rights, which should be opposed. Some traditional populations permit abusive treatment of women. They may utilize dangerous practices such as trial by ordeal as a basis for determining guilt. These traditions may be locally legitimate to the practitioners, but should be actively discouraged in the formal rule of law system. Correcting abuses however, does not require reformers to completely ignore or dismiss the larger legitimate system in which they are imbedded. Instead, avenues of appeal should be established along with more direct efforts to eliminate inappropriate practices. But such efforts must be founded in acceptable forms of self-rule and social consensus-especially when the goal is to change that consensus - rather than through the imposition of legislation that may be perceived as foreign or adverse to local needs.

Law is more than legislation, but legislation does define a primary arena for ROL interventions. The UN definition may not include all sources of law, but unlike many ROL practitioners, at least it includes all such laws. The design and implementation of ROL projects is often limited to only those laws falling within "human rights" rubric. The right to a fair trial is undeniably important, but so are rights that directly affect the economic health of a country. Economic rights are human rights, and should be considered from an ROL perspective as well. Unfortunately, development agencies often divide expertise into "democracy and governance" and "economic growth"

16. A shura is an Arabic term meaning "consultation." Merriam Webster Online Dictionary explains that "[i]t is believed to be the method by which pre-Islamic Arabian tribes selected leaders and made major decisions." See Extended Definition: Shura, http://websters-online-dictionary.org/definitions/ shura. Also, "The title of the XLIInd Surah of the Quran. Taken from the 36th verse, in which the believers are commended for taking consultation together." Thomas Patrick Hughes, A Dictionary of Islam (2001). 
disciplines even though growth is directly affected and managed through legislation and regulation.

Inappropriate exclusion of commercial or other legislation significantly undermines ROL work in two ways. First, it leads to missed opportunities on the economic growth side. Commercial law projects far too often fail to employ processes and approaches that would increase ownership, legitimacy, and stability. There seems to be a general assumption that commercial laws, like components in a machine, can simply be improved with upgraded versions that will cause the economy to adjust appropriately. To the contrary, the economic system is just as dynamic and organic as democracy and governance systems. Assistance that bypasses legitimate processes with economic fiat undermines itself along with the larger ROL landscape.

Second, the false division between human rights and economic rights leads many human rights practitioners to underestimate the economic impact of their work, or economic causes of governance problems. For example, much assistance to improved performance of courts in former Yugoslavia has been impeded by tax regulations requiring companies to sue debtors before writing off bad debts. Many courts were inundated by trivial suits; in Sarajevo, utilities companies filed tens of thousands of claims worth less than $\$ 50$ each, virtually shutting down the Municipal Court. ${ }^{17}$ Judicial projects limited to ROL research tended to miss such systemic fractures.

Governance includes economic governance. Indeed, one of the most telling international rankings of governance today is the World Bank's Doing Business Project, ${ }^{18}$ which measures the quality of business regulation. Even a cursory glance at the rankings reveals extensive issues in more general ROL quality. Business regulation reforms recommended by Doing Business frequently address problems of corruption, often more effectively than do traditional ROL anti-corruption projects.

Effective rule of law assistance requires a broader understanding of the laws that comprise the legal system, including unwritten rules of behavior and the full range of written rules. Yet even a broader definition will be insufficient unless it recognizes that rules cannot be affective unless they are

17. An example of this Yugoslav system was incorporated as Article 4 of the Corporate Tax Code of Bosnia and Herzegovina (since amended), as cited in USAID, Practical Solutions For INTRACTABLE Problems: File's Comprehensive Court Report and Recommendations for Bosnia and Herzegovina 4 (2005), http://pdf.usaid.gov/pdf_docs/PNADI318.pdf. Comments on the impact of such regulations on low-value filings in Sarajevo Municipal Court are based on the author's research and experience.

18. The World Bank Group, Economy Rankings, DoINGBusINEss.org, http://www.doingbusiness .org/economyrankings/ (last visited Oct. 9, 2010) (providing rankings for world national economies). 
known among those expected to enforce or comply with them. Such knowledge cannot be assumed; it must be created. Public promulgation does not necessarily lead to public knowledge, and public knowledge is not the same as public education. The implications for programming are significant. First, given the relational aspects of lawmaking, it is important to involve those who should know about legal reforms in the design and drafting process. For example, the company law of Macedonia was reformed in two phases during the past decade. During the first, a small group of experts worked on the draft, then had it pushed through a compliant legislature and enacted on paper. Once the foreign experts went home however, local opponents had the reforms nullified. In the second phase, foreign and local experts vetted the recommended reforms among the business community - the CEOs, lawyers, accountants and others who would have to implement it. This inclusive process created knowledge, consensus, and, ultimately, implementation.

A second practical implication flows from the need for knowledge. Reforms require education. It is not possible (nor desirable) to include all stakeholders in the design and drafting process, but all must be informed. Public education helps to establish awareness and understanding of the change, but also helps to define the relationship under which rule can be attempted. If the process has been participatory, public education can send the message that the government is working with the affected population, not simply dictating new mandates by fiat. Such consensus also permits industry organizations, professional associations, and other civil society organizations to assist in enforcing the new standards. Professional education and even secondary curricula must also be developed to extend the knowledge base, but public education is essential. Rule cannot be exercised on the basis of ignorance.

Effective ROL practice requires an improved understanding and definition of "laws." The definition must embrace traditional and customary law, and practitioners must embrace the full range of promulgated laws, not just favorites of a particular development subspecialty. Finally, practitioners must ensure that laws are known; without knowledge (which requires more than public promulgation), legislation is little more than an unenforceable good idea.

\section{The Problem of False Cognates}

False cognates are words that look or sound the same, but which are quite different in content. For example, Portuguese, like English, has evolved among different peoples living at great distance from one another with limited 
communication, giving rise to some interesting misunderstandings. Both Brazilian and standard Portuguese use the word bocada, derived from the word for "mouth," meaning "a mouthful." Here the confusion begins. In Brazil, a mouthful is a large amount, denoting many items in a small space. In Portugal and some of its former colonies, bocada refers to a small amount - no more than a mouthful. When an unknowing Brazilian orders a bocada of some item from a Portuguese, she will expect a lot and get a little, and insisting correctly that the amount is not a bocada, while the Portuguese correctly insists that it is.

"Government" is also a false cognate, on at least two levels. First, "government"-for those from the Enlightenment tradition of social contract - is generally understood to refer to a set of formal institutions with a mandate to facilitate freedoms and control abuse. In much of the world, "government" is the entity that controls freedoms and facilitates abuse.

The word also achieves false cognate status on a second level. For some, "government" is a comprehensive system of checks and balances that includes executive, legislative, and judicial functions at the national and subnational level. For others, it refers to the national executive branch only.

The UN appropriately identifies rule of law as a "principle of governance," which presupposes the use and existence of "government." Unfortunately, the problem of false cognates (which are no fault of the UN) creates confusion in rule of law assistance as it injects inappropriate assumptions about the nature of the entity being assisted, while unnecessarily limiting the scope of the assistance.

In their book, Violence and Social Orders, North, Wallis, and Weingast posit a continuum of governmental forms ranging from limited to open access orders. In limited access systems (which can in turn range from highly restrictive to almost open), government systems are established to share the rents of government among a limited coalition of elite interests. This subset of the larger population has rights vis-à-vis each other, but does not extend the franchise broadly to the general population. In other words, the system is based on privileges, not rights. Open access orders (which they limit to only 26 existing states) evolved to extend the franchise and provide rights to the larger population on the basis of citizenship. To illustrate, Zimbabwe is a limited access order while Sweden has open access.

Yet whatever the place on the continuum, all of these governing entities are referred to as "governments." They are treated as having the same basic underlying logic of protecting the general welfare, even though many governments have no intention of expanding the benefits of rule beyond their 
own clique, clan or community. Little distinction is made between liberal democracies and extractive kleptocracies.

This poses a problem. When one government provides subsidies to another government to enable the recipient to improve its rule of law, there is high likelihood of failure if the recipient's purpose in receiving assistance is to benefit a small coterie of privileged individuals. If, however, the development community were to analyze the nature and internal logic of the various recipient governments, the nature of assistance should dramatically change.

It is high time to make those changes. The Millennium Challenge Corporation (MCC) pioneered one approach worthy of further study and emulation. Under MCC guidelines, recipient governments must attain certain levels of competence and control of corruption in order to obtain assistance. That is, they must demonstrate at least a minimum commitment to rule of law. If the government thereafter backslides on these indicators MCC can and will cease assistance.

Easterly raised a red flag about this problem a decade ago when he described a system of incentives that encouraged developing country governments to engage in the pretense of improvement without actually improving, simply because improvement would lead to less development assistance. ${ }^{19}$ Instead of making necessary changes, resources have too often been squandered, presumably among the political elite and their clientele. Unfortunately, those in office are not personally responsible for indebting their countries with failed assistance efforts; it is the impoverished taxpayer who picks up the tab. Perhaps it is time to consider assistance contracts that include personal civil or criminal liability-foreign or international tribunals - for those responsible for looting the government coffers. The current system is not working.

The second level of false cognates mandates a second set of changes. Many - if not most - rule of law assistance programs target the national executive branch. ${ }^{20}$ Yet government, as the term is popularly employed, includes legislative and judicial branches at the national, county, and

19. William Easterly, The Illusive Quest for Growth: Ventures and Misadventures of ECONOMISTS IN THE TROPICS (2002).

20. It is true that there are a large number of judicial reform projects addressing systemic issues for courts of all instances; yet until recently these projects often neglected capacity building and assistance for enforcement, thus resulting in unenforceable judgments. These flaws are increasingly being corrected. Likewise, a number of legislative strengthening projects have been undertaken, but often there is no connection with legal reform projects focused on the executive ministries, even when funded by the same donor. Fortunately, learning is an iterative process, and changes are afoot. Slowly. 
municipal level. Reforms adopted as law in the capital must often rely on municipal implementation, but too often no assistance is provided at that level to build capacity for implementation. When the same term is used to describe the executive alone as well as the broader system of checks and balances, confusion results.

Explicit recognition of the expansive meaning of "governance" and "government" would undoubtedly help to redirect efforts for more effective assistance. But it would do more, as well. As the late Congressman Tip O'Neil famously stated, "all politics is local." ${ }^{21}$ Strengthening representative capacity at the local level-whether through assistance to municipal governments or working with legislators to better respond to their constituencies - promotes legitimacy by increasing access to government for the general population. Such efforts help to extend the franchise of citizenship beyond the center and create competition among subnational governments to better serve their populations. This type of rule of law reform has been promoted from an economic growth perspective through the World Bank's Doing Business project by ranking subnational governmental units against the capital and each other. ${ }^{22}$ In Mexico, ranking of states has resulted in significant reforms at the state level, including improvement of local courts.

Positive impact from rule of law efforts can be improved if these false cognates are understood for what they are. The political will necessary for far reaching reforms must be negotiated within the national socio-political context; it cannot be mandated from abroad through conditionalities, at least not with meaningful impact. ${ }^{23}$ Assistance at the subnational or local level can help to create political counterpoint needed to promote reforms that could dislodge vested interests at the center. Moreover, broader stakeholder participation improves ownership and quality of ROL efforts. Widespread capacity assistance can help to create a foundation for renegotiating the relationships that define consensus and create accountability for the rule of law. Focusing on the center concentrates power at the center, which weakens the national accountability structure and retards the rule of law.

21. http://en.wikipedia.org/wiki/Tip_O'Neill.

22. See The World Bank Group, Doing Business in Mexico 2009, DoIngBusiness.org, http:// www.doingbusiness.org/Subnational/exploreeconomies/Mexico2009.aspx (last visited Oct. 9, 2010).

23. Conditionalities are problematic, in great part because they run the danger of short-circuiting the fundamentals of governance by sometimes making the recipient governments accountable to the donors instead of to the citizens of the recipient countries. 


\section{The Problem of Collective Nouns}

Collective nouns appear in the singular but are actually plural in nature: a "herd" of cows, a "flock" of sheep. "Deer" may be singular or plural, depending on context. In addition to provoking American consternation when The Economist's British editors pair plural verbs with superficially singular subjects (e.g., "the team are expected to succeed"), collective nouns are also a problem for the rule of law assistance.

Like the word "deer," the term "reform" may refer to one or many events. In development practitioner parlance, it is often used to denote passage of a new law or regulation. For example, a development professional in Mozambique noted that a project had accomplished a number of significant reforms, but that they had not been implemented. The common lay person might wonder how a reform can be successful without being implemented, but professionals understand. Unfortunately, the professionals are wrong.

Reform is not an event; it is a process and a system. The UN definition of rule of law provides a strong sample of the multifaceted nature of the concept, implying the existence of a complex system. Individual events, such as adoption of new legislation, are significant only to the extent that adoption is part of such a system and leads to implementation. In many developing countries, this is simply not the case, or at least not for implementation of donor-mandated laws that are adopted on the basis of conditionality without local buy-in.

The purpose of law is to structure socio-economic behavior. The purpose of reform is to change that behavior, either by prohibiting existing behaviors or permitting new behaviors. A reform is successful only when the targeted behavior has changed.

The problem of treating "reform" as a singular noun appears to arise from several sources. One of these is the use of "law" as a proxy for the complex system that produces laws. In well developed participatory governments, laws are passed as a result of participatory negotiation that leads to consensus on solutions, which can then be converted to law and implemented through a wide array of agencies and individuals that move into action whenever a law is passed. In such countries, it is common for negative events to provoke an outcry of "we need a law" to rectify that. What is often forgotten is that the law will only be produced after five to seven years of negotiations, public hearings, and revisions in most democracies (or twelve years on average in the Netherlands), followed by years of adapting and adopting existing systems to ensure implementation. "Reforming a law" sounds like a singular event, whereas the reality is far different. 
Poor understanding of reform complexity, coupled with the demand for measurable outcomes by those who fund reform projects, plus limited available funding come together to create the perfect conditions for focusing on passage of legislation as a proxy for implementation of new policies. Unfortunately, measurable reforms may not be the same as meaningful reforms.

Correcting this syndrome will take more than explaining the plural nature of the term "reform." It might be helpful if practitioners could adopt new language, given how difficult it is to change underlying perceptions of a term. It would be far better to focus on the "reform process" or the "reform system." This process incorporates four distinct stages, with numerous participants at each stage. It begins with (1) problem identification, which leads to (2) policy formulation (often expressed through law or regulation). Once the policy is in place, it must be (3) implemented, and the implementation must be (4) monitored and evaluated. This often results in identification of new problems, and the cycle begins again to refine the outcomes. ${ }^{24}$

Today, "reform" identifies only one subset of the process - passing a law. Changing the language will change the focus. And changing the focus should lead to far greater positive impact.

\section{The Problem of Verb Tenses ${ }^{25}$}

The element of time and certainty is handled grammatically through verb tenses. Much rule of law assistance effort incorporates a defined future indicative: "We will establish rule of law through a 3-5 year program." Also popular is the present hortatory: "You will adopt this reform now in order to receive further assistance." Yet most rule of law work can best be conceived as the perpetual present, if not the perpetual subjunctive present. In other words, establishing and maintaining the rule of law requires constant, consistent effort, with no end date in sight and no consistent guarantee of success. It is never fully achieved, but only refined and (hopefully) improved over time.

24. See generally USAID, Policy Reform Lessons Learned: Ten Years of Economic Growth Related Policy Reform Activities in Developing Countries (2007), available at $\mathrm{http}: / / \mathrm{pdf}$.usaid.gov/ pdf_docs/PNADK260.pdf, for a more complete explanation of the policy reform process.

25. In the interest of full disclosure (especially to readers for whom English is a second language), the author wishes to note that some tenses have been blatantly fabricated for illustrative purposes and may not accurately reflect definitions or understanding of professional grammarians. 
The UN captures this permanent present focus when describing the rule of law as "a principle of governance in which all persons ... are accountable to laws ...." ${ }^{, 26}$ For the system to work, accountability must be maintained over time. Bromley and Anderson put it well: "Policy reform is the continual process of institutional refinement and re-creation though which economic coherence is sustained and enhanced. ${ }^{, 27}$ As already noted, reform is a dynamic system subject to myriad influences. Programming must take this into account.

Development projects are often subject to or even driven by a demand for short-term "quick wins" or "low-hanging fruit." These initiatives are the crack cocaine of the development community, providing immediate "benefits" but little if any long-term positive impact. Indeed, USAID recently commissioned an evaluation of rule of law projects in Africa, which stated:

\footnotetext{
This study overwhelmingly confirmed that short-term and limited-focus ROL interventions generally fail to achieve significant and sustained impact in Africa. Programs designed to overcome problems with political will, lack of consensus, or corruption will be particularly challenging and will require patience and longer-term engagement. Donor programs emphasizing more gradual, less immediately ambitious, and longer-term programming approaches are more likely to be successful and sustainable. ${ }^{28}$
}

High-profile, short-term achievements should not be avoided, but should be incorporated within a long-term, long-range program of which they are a mere element, not the primary focus. It is often necessary to prove that change can happen in order to change expectations and build momentum for prolonged efforts, but short-term successes (such as a regulatory change by the stroke of a minister's pen) cannot stand separate and apart from systemic, prolonged change.

This has implications for funding. The life cycle of most projects is no more than five years, and often no more than three years. Adopting new legislation in developed countries takes 5-7 years after a draft law has been presented for consideration, and this does not take into account prior policy discussions or subsequent implementation requirements. Court reform in former Yugoslav republics has required a minimum of ten years before meaningful improvements have been noticed.

26. The Rule of Law and Transitional Justice in Conflict and Post-Conflict Societies: Report of the Secretary-General, supra note 9, at 96.

27. Daniel W. Bromley \& Glen D. Anderson, Creating Economic Coherence Through Policy Reform: The New Development Imperative 4 (2010).

28. Stromsen ET AL., supra note 1. 
Rule of law assistance should be planned in meaningful stages, with next steps programmed as projects come to end. Perpetual planning and adjustment will be needed. There will be setbacks. "Bringing coherence to vulnerable states cannot be based on a strategy of forcing national leaders against their will, to change their policy outlook and motivation." ${ }^{29}$

If funding is not likely to be available to complete the critical mass of steps needed to ensure success, practitioners should reconsider what kind of projects they can undertake. It may be more fruitful to promote a program of public education on rule of law issues, thus stoking popular demand for change, than to attempt systemic reform that will be stillborn when the project ends.

Reform is perpetual.

\section{The Problem of Prepositions}

Prepositions cannot stand alone in a sentence or a phrase. They must take an object. This creates a number of questions: should assistance be provided to, for, with, on behalf of, or in spite of the government, civil society, the private sector, others? If rule of law requires accountability, to whom must assistance providers be held accountable? If transparency is a mandate, transparency of what-process, result, impact, donor funding, political compromises, interventions of entrenched interests? Many of these questions are beyond the scope of this paper, if not the patience of the readers. Several are crucial.

The Paris Declaration calls for "mutual accountability" of governments to each other in pursuing development objectives. The Hague Institute for the Internationalization of Law has taken this to a more granular level and is currently considering accountability of rule of law assistance providers. While there is agreement that practitioners should be accountable, the issue is accountable to whom? As structured, it is not clear who the beneficiary of rule of law assistance is or should be.

Assistance is needed where rule of law is weak, which means that the general population is suffering from the government's failure to provide this invaluable public good. Consequently, it can be argued that assistance providers should be serving "the common good" or the general population by promoting reform of an errant or inadequate governmental system. To some extent, the government can be seen as the problem, yet the structure of 
international donor assistance tends to define the government as the primary recipient or beneficiary. When government is not committed to reform, accountability to government is inappropriate; yet bypassing the government on behalf of the citizens can be seen as undermining government legitimacy, and even as subversive activity. Indeed, a number of poor rule of law performers attempt to limit or control donor access to the private sector and NGOs to avoid internal challenges to their authority.

Once projects are permitted, other prepositional problems arise. Many rule of law projects run afoul of best practices ${ }^{30}$ by doing the work of legislative drafting without meaningful involvement of stakeholders, thus doing the work for them instead of with them. In these cases, assistance becomes replacement, with foreign advisors building their resumes, but not the capacity of the local counterparts who must live with the new laws. A senior economist with USAID stated the issue clearly when examining a rule of law project in Africa: "Why are we drafting their laws?"31 She understood that law is more than legislation, and leaving documents for parliament to pass is not the same as enabling local specialists to better manage their own legal system.

Clearer definition of beneficiaries will enable assistance providers to better plan their programs for greater effect. But that effect will not be achieved without appropriate mechanisms that build local capacity to continue the perpetual process of reform well after the foreign experts have departed.

\section{SUMMARY}

External programs can have a positive impact on establishing the rule of law in developing countries, but efforts are often limited by poor understanding of the nature of the assistance required. Success depends on the willingness and capacity of host countries to restructure their societal relationships toward a system of participatory governance that produces consensus on the laws to be obeyed and accountability of rulers to obey them.

Where there is will but poor capacity, external assistance can be very effective in achieving the rule-of-law goals and objectives, provided that sufficient time and funding are allotted to the effort. One-off interventions

30. See generally Ann Seidman et al., Legislative Drafting for Democratic Social Change: A MANUAL FOR DRAFTERS (2001) for well established guidelines in legislative assistance and International Consortium for Law and Development, International Consortium for Law and Development, ICLAD, http://www.iclad-law.org/ (2009).

31. Private conversation with author, January 2010, Juba, Sudan. 
achieve little long-term impact, if any. Assistance providers must take care that they are building capacity, not replacing local capacity with foreign expertise; otherwise any gains made are likely to be superficial and vulnerable to reversal.

Where will to change is lacking, few rule of law programs will be effective. But that is no reason to give up; opportunities to promote rule of law abound when providers understand that all development assistance has implications for the rule of law. Any program that increases participation in policymaking promotes rule of law; any program that promotes transparency and accountability promotes rule of law. Donors should be shrewd: Rule of law can be incorporated into procurement reforms, business climate reforms, methods of humanitarian assistance, healthcare improvements, and investments in education or agriculture. Indeed, failure to deliberately promote rule of law in any external project is precisely that: a failure, and one that undermines rule of law.

Through expanded vision and scope, there are expanded opportunities for positive impact. Recognizing the underlying relational dynamics mandates a broader relational approach, involving public agencies of all sorts-executive, legislative, judicial; national, subnational, municipal — as well as supporting the development of competing voices in civil society, the media, and the private sector. This will lead to greater capacity for participation and accountability.

The grammar of reform, as outlined here, is an invitation to fundamentally rethink the purpose and nature of reform in order to design the methods needed to provide effective external assistance. The status quo in rule of law work is insufficient; but change will require better thinking, which in turn requires better language.

Admittedly, this focus on "grammar lessons" is a contrived rhetorical device for identifying deeper problems of reform assistance. Yet the language of reform incorporates and perpetuates ideas that affect that assistance. Rule of law must be understood more broadly; it must incorporate terms and concepts that lead and instruct rather than mislead and obstruct. An improved grammar of reform is needed if rule of law is to become a worldwide reality. 